\title{
Obituary
}

\section{KENNETH MANLEY SMITH, 1892-1981}

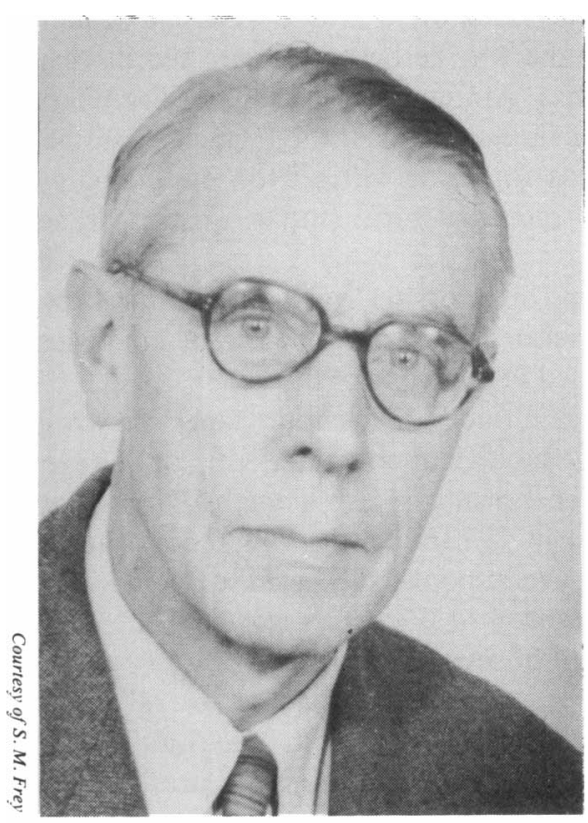

A pioneer of plant and insect virology Dr Kenneth Manley Smith died on 11 June 1981 at the age of 88 . He was a founder member and one of the few Honorary Members of the Society for General Microbiology.

Kenneth Smith was born in 1892 at Helensburgh near Glasgow of English parents, his father being a civil engineer. He was educated at Dulwich College (1907-1911) and gained a scholarship to the Royal College of Science (now part of Imperial College). He graduated with second class honours in 1914 and almost immediately enlisted as a private in the 14th Battalion of the London Scottish Regiment. He took part in one of the last charges of kilted infantrymen and was invalided out in 1915. He then returned to the Royal College of Science and started his research career studying the anatomy of Amphioxus.

Kenneth Smith left London in 1920 to take up an appointment as lecturer in Agricultural Entomology at Manchester University. He became interested in numerous plant pests such as onion and carrot root flies and developed methods for their control. He was awarded an MSc in 1922 and a DSc in 1926 by Manchester University.

In 1927, Redcliffe N. Salaman induced the Ministry of Agriculture to found the Potato Virus Research Station at Cambridge. Kenneth Smith was recruited as entomologist and thus started his long association with viruses. By 1931 he had achieved the separation and identification of the potato virus $\mathrm{X}$ and $\mathrm{Y}$ complex, and he and the rest of the group went on rapidly to recognize and characterize several other potato viruses. Kenneth Smith studied the relationships between these viruses and their vectors and was among the first to realize that viruses differed in their vector relationships. To his chagrin he found that Cambridge University only recognized degrees from Cambridge, Oxford and Trinity College, Dublin; therefore he took a Cambridge PhD.

When Salaman retired in 1939 Kenneth Smith became Director of the Research Station. He realized that potato viruses were not restricted to potatoes and that there were many viruses of other hosts; therefore he changed the name to the Plant Virus Research Station. Subsequently it became the Plant Virus Research Unit and, finally, the Virus Research Unit of the Agricultural Research Council. The facilities developed by Salaman were naturally geared to work on potatoes and the laboratory consisted of about 18 feet of bench at the end of the potato storage barn with one cold tap and an electric hot plate. With the expanded interests of the Plant Virus Research Station more laboratory space was obviously needed. Kenneth Smith arranged with David Keilin, Director of the Molteno Institute, to have two and later three rooms there. They brought various people together and Kenneth Smith worked with, among others, Douglas Lea and Roy Markham on the effects of ionizing radiation on the inactivation of viruses. He also co-operated with Lea on the theoretical aspects of aphidtransmission of plant viruses. 
At the same time Kenneth Smith continued isolating and describing many new viruses infecting agricultural and horticultural crops including tobacco necrosis, tomato bushy stunt and turnip yellow mosaic viruses. He was interested in the physical properties of these viruses and worked extensively on filtration studies in an attempt to measure particle size. When the electron microscope was developed he was one of the pioneers in its application to the study of virus particles.

During the Second World War Kenneth Smith designed methods to improve the health of potatoes. He developed the system of producing nuclear stock of virus-free tubers, a scheme which is still the main one used in this country. After the war he became interested in virus diseases of insects, especially those of the Lepidoptera. Among the viruses he discovered were the cytoplasmic polyhedrosis group and Tipula irridescent virus; the former group has been named Smithia after him. He developed methods for using viruses for the biological control of insect pests. He also carried out extensive ultrastructural studies on the viruses using the electron microscope.

The atmosphere at the Virus Research Unit under his directorship was happy and relaxed and his work on plant and insect viruses attracted visitors from many different countries. Everyone was made to feel at home and became absorbed in the work of the group.

Kenneth Smith was a prolific writer. As well as a large number of scientific papers he wrote many textbooks on virology. His wide knowledge of the biological characters of plant viruses and the numerous viruses that he was first to describe is shown in A Textbook of Plant Virus Diseases first published in 1937; he entirely revised it in 1973 when he was more than 80 years old and it still remains a standard text. He wrote several books successfully popularizing the science of virology. He was a co-editor of Advances in Virus Research from 1953 (Volume 1) until his death and was on the editorial board of several journals.

After his retirement he continued working at the Virus Research Unit for several years. Then, at the age of 70, he moved to Pittsburgh, Pennsylvania, to work with Max Lauffer and then on to the Botany Department at the University of Texas in Austin for 5 years. In 1969 he finally returned to Cambridge and continued his writing. He had two successful operations to replace his hip-joints and remained active until his death.

Kenneth Smith was granted many honours including Fellowship of the Royal Society (1932), the Leeuwenhoek Lectureship of the Royal Society (1953) and the Masters Memorial Lectureship of the Royal Horticultural Society (1949). He was made a CBE in 1956 . He served on the Council of the Royal Society (1956-58). In 1943 he was co-opted on to the committee which was responsible for founding the Society for General Microbiology and served on the Committee of the Society from its inauguration in 1945 until 1948. The Society made him an Honorary Member in 1972 and he was an Honorary Member of the Association of Applied Biologists.

Kenneth Smith married Germain Marie Noel in 1923 and they had one son. He was very fond of his family and his home where he enjoyed his chief hobbies of gardening and of an extensive collection of tropical butterflies and moths. As a keen cyclist he was strongly opposed to the 'horseless carriage' and insisted on cycling the 5 miles to and from the laboratory in all weathers throughout his working life. In retirement he installed an exercise bicycle in his home, which he used each day.

He was a reserved man with firm opinions which he never forced on people. His quiet sense of humour added greatly to conversations. Always the perfect gentleman he never raised his voice in argument but his masterly command of English and his keen dry wit were powerful weapons which added interest and dimension to any subject. As a scientist he was meticulous in his observations. He laid the foundations for much of plant and insect virology.

R. HULL 